\title{
THE ROLE OF FACULTY OF MEDICINE AND HEALTH SCIENCES IN THE PREPARATION OF HUMAN RESOURCES FOR ACADEMIC HEALTH CENTER CONCEPT AT MUHAMMADIYAH GAMPING HOSPITAL, YOGYAKARTA
}

\author{
Vika Habsari Budi Utami, Arlina Dewi, Ekorini Listiowati
}

Masters Program in Hospital Management, Universitas Muhammadiyah Yogyakarta

\begin{abstract}
Background: The concept of Academic Health Center (AHC) refers to combination of education, research, and health service functions. Faculty of Medicine and Health Sciences Universitas Muhammadiyah Yogyakarta (FKIK UMY) is an educational institution implementing study programs in medicine, dentistry, nursing, and pharmacy. The AHC concept is potentially applicable in Indonesia, especially at FKIK UMY, to improve the quality of human resources to comply with the Competency Standard of Indonesian Doctors 2012 (SKDI 2012) and the WHO 5 star doctors. This study aimed to assess the role of faculty of medicine and health sciences in the preparation of human resources for AHC concept at Muhammadiyah Gamping Hospital, Yogyakarta.

Subjects and Method: This was a qualitative study conducted at Muhammadiyah Gamping Hospital, Yogyakarta, from April to May 2018. A sample of 6 key informants from representatives of the dean's office at FKIK UMY and several teaching staff of FKIK UMY. The dependent variable was preparation of human resources for AHC concept. The independent variable was the role of FKIK UMY. The data were collected by in-depth interview and processed using descriptive method.

Results: FKIK UMY had implemented the AHC concept based on 4 aspects: (1) Organizational (bureaucracy), (2) Policy (regulations), (3) Financial (financial support), (4) Resources (competent human resources and teaching hospital). The AHC concept was able to facilitate the role of FKIK UMY in implementing Tridarma of higher education. FKIK UMY management, teaching hospital management, and the general health advisory council (MPKU), were expected to implement joint collaboration efforts to achieve Tridarma. FKIK UMY had reached the stage of legal collaboration and coordination with MPKU and teaching hospital to realize the AHC concept.

Conclusion: The AHC concept has been able to facilitate the role of FKIK UMY in implementing Tridarma of higher education. FKIK UMY has reached the stage of legal collaboration and coordination with MPKU and teaching hospital to realize the AHC concept.
\end{abstract}

Keywords: FKIK UMY, Tridarma of Higher Education, Academic Health Center

\section{Correspondence:}

Vika Habsari Budi Utami. Masters Program in Hospital Management, Universitas Muhammadiyah Yogyakarta, Jl. Lingkar Selatan, Tamantirto, Kasihan, Bantul, Yogyakarta 55183. Email: vikahbu@gmail.com Mobile: 08524626022 